\title{
Composition, Digestibility, and Microbiological Quality of the Animal-Origin Meal
}

\author{
Julia Marixara Sousa da Silva (Corresponding Author)
}

Master's degree in Animal Science by the Federal Goiano Institute - Rio Verde Campus Federal Goiano Institute - Rio Verde Campus Sul Goiana Highway - km 1 - Rio Verde Rural Zone - GO - Brazil ZIP Code: 75.901-970. E-mail: marixaraj@ gmail.com

\section{Christiane Silva Souza}

$\mathrm{PhD}$ in Biochemistry from the Federal University of Viçosa- Avenida PH. Rolfs, no University Campus Viçosa - MG TEL: (31) 3612-4616 Brasil.

E-mail: christiane_s_souza@hotmail.com

\section{Alison Batista Vieira Silva Gouveia}

Master's degree in Animal Science by the Federal Goiano Institute - Rio Verde Campus Federal Goiano Institute - Rio Verde Campus Sul Goiana Highway - km 1 - Rio Verde Rural Zone - GO - Brazil ZIP Code: 75.901-970. E-mail: alisonmestre28@gmail.com

\section{Weslane Justina da Silva}

Master's degree in Animal Science by the Federal Goiano Institute - Rio Verde Campus Federal Goiano Institute - Rio Verde Campus Sul Goiana Highway - km 1 - Rio Verde Rural Zone - GO - Brazil ZIP Code: 75.901-970. E-mail: weslanejds@ gmail.com

\section{Lorrayne Moraes de Paulo}

Zootechnist at the Federal Institute of Goiano; Department of Animal Science. Rio Verde-GO Brazil. Federal Goiano Institute- Rio Verde Campus South Goiana Highway - km 1 - Rio Verde Rural Zone - GO - Brazil ZIP Code: 75.901-970.

E-mail: lorraynemoraesrv@gmail.com

\section{Fabrício Eumar de Sousa}

Master's degree in Animal Science by the Federal Goiano Institute - Rio Verde Campus - 


\title{
Macrothink

Federal Goiano Institute - Rio Verde Campus Sul Goiana Highway - km 1 - Rio Verde Rural Zone - GO - Brazil ZIP Code: 75.901-970 E-mail: fuscafabricio@hotmail.com

\section{Jiovanna Gonçalves Sousa}

Zootechnist at the Federal Institute of Goiano; Department of Animal Science. Rio Verde-GO Brazil. Federal Goiano Institute Rio Verde Campus South Goiana Highway - km 1 - Rio Verde Rural Zone - GO - Brazil ZIP Code: 75.901-970. E-mail: jiovannaji@gmail.com

\section{Cíntia Silva Minafra e Rezende}

$\mathrm{PhD}$ in Animal Science from the Federal University of Goiás - UFG, Federal University of Goiânia Goiânia Highway, km 8 s / n Campus - Samambaia, Goiânia - GO, 74001-970Goiânia-GO, Brazil. E-mail: cintia.minafra@ufg.br

\section{Fabiana Ramos dos Santos}

$\mathrm{PhD}$ in Animal Science from the Federal University of Goiás - UFG, Federal University of Goiânia Goiânia Highway, km 8 s / n Campus - Samambaia, Goiânia - GO, 74001-970Goiânia-GO, Brazil. E-mail: fabiana.santos@ifgoiano.edu.br

\section{Cibele Silva Minafra}

$\mathrm{PhD}$ in Biochemistry from the Federal University of Viçosa - Professor at the Goiano Federal Institute; Department of Zooetnia. Rio Verde - GO Brazil.

E-mail: cibele.minafra@ifgoiano.edu.br

Received: Dec. 18, 2019

doi:10.5296/jas.v8i1.16531
Accepted: Feb. 3, 2020

Published: Feb. 25, 2020

URL: https://doi.org/10.5296/jas.v8i1.16531

\begin{abstract}
There is currently a growing interest of animal nutritionists and farmers in the use of by-products and/or agro-industrial residues in feeds. The purpose is to reduce production costs, since feed represents nearly $70 \%$ of the cost of production, as well as to allocate waste properly, minimizing potential environmental impacts. The characteristics of the residues used and their physical and/ or chemical limitations should be known, providing nutritionist with the correct information for the best choice and use of these ingredients for animal nutrition. This study aims to characterize the centesimal and energetic composition,
\end{abstract}


digestibility, and microbiological quality of animal-origin meals in non-ruminant feeds. Samples of animal-origin meals - AOM $(n=210)$, hydrolyzed feather meals $(n=70)$, chicken offal meal $(n=70)$, and pig offal meal $(n=70)$ were evaluated. The following variables were determined: moisture, crude protein, amino acids, ethereal extract, ash content, FAO grain size analysis, and protein digestibility. Peroxide and acidity levels were determined to evaluate the oxidative process. The microbiological quality of AOM evaluated by the presence/absence of Salmonella spp.; the apparent metabolizable energy was verified by the indirect method using prediction equations. The amounts of proteins, minerals, amino acids, and energy differed from those reported in the literature. These results were possibly due to the different operational processes performed in each one of the experiments, as well as the proportions of constituents in the compared raw materials compared. Moreover, we observed that the AOM is within the Brazilian hygienic-sanitary standards.

Keywords: Grain size, Metabolizable energy, Rancidity, Salmonella, Viscera

\section{Introduction}

In agribusiness, chicken meat and pork production chains constitute important segments that generate employment and income for people. Besides the expressive amounts of animal protein produced and exported, there is the generation of the most varied co-products and/or by-products from the slaughter process. The by-products consist of offal, feathers, sebum, blood, meat, and bones (Reis et al., 2013).

In Brazil, the animal recycling industry works to prevent significant volumes of animal origin co-products (AOC) from inappropriately discharged in the environment. In 2014, 12.4 million AOCs tons were processed, and not destined for human consumption, generating 5.3 million tons of meal and oils. There was a production of 3.41 million tons of animal meal, of which $15.6 \%$ came from feathers, and 18.3\% from offal (Brazilian Animal Recycling Association - ABRA, 2016).

The production of animal by-products presents an average annual growth of $25.4 \%$, which shows the potential of these products, especially meat and bone meal, which accounts for $86 \%$ of Brazilian foreign sales. The concentration of flour and fat manufacturing is proportional to the concentration of factories of animal products, as a symbiotic relationship of the production chain, benefiting the environment of those regions (Silva et al., 2018).

Os coprodutos de origem animal são definidos como corpos inteiros ou partes de animais mortos e outros produtos provenientes de animais que não se destinam ao consumo humano, incluindo oocistos, embriões e sêmen. As principais fontes dos coprodutos são o abate de animais destinados a consumo humano, a produção de alimentos de origem animal e o abate sanitário de animais (ABRA, 2016; Geraldes, 2014).

Animal-origin meals - AOM is an important source of calcium, phosphorus, amino acids and energy (Ruis et al., 2013). The use of animal by-products in the monogastric diet aims not only to reduce feed costs, but also to be an alternative source of protein (Carvalho et al., 2012). Thus, the effect of animal meal on animal performance can be modified by several factors, including processing, an origin of the co-product used, and use of additives and 
antioxidants (Aguiar et al., 2014).

The inclusion of up to $8 \%$ of animal meal in the feed, in addition to meeting the protein needs of the bird, plays an important role in nutrient recycling and environmental preservation, when considering the pollutant content of slaughterhouse co-products. Thus, harnessing waste from the meat industry for the production of animal meal (FOA) is of paramount importance in the economic and environmental aspects (Rostagno et al., 2017).

However, the lack of standardization in the manufacturing process can be inconvenient for use, as it causes variations in nutrient and energy content (Geraldes, 2014). Thus, the use of FOA in feed is limited by knowledge of the origin of the material and its processing, factors that affect the digestibility of nutrients provided by them. Therefore, technologies that improve the digestibility of these ingredients in poultry feed are important.

Numerous factors involved in the acquisition process of raw materials that have a wide variation in chemical composition depending on the type and proportion of materials (meat, blood, bones and fat) used; the form of processing, in this case the most influential factor is the temperature used in the cooking of the raw material, which can modify the chemical composition and nutritional (digestibility and metabolizability in nutrient) and microbiological quality AOM. However, there are economic, sanitary, and nutritional reasons for the use of AOM, such as lowering the final feed price, and providing a suitable destination for the waste generated by slaughterhouses (Eyng et al., 2012, Troni et al., 2016).

The continuous study of the composition of ingredients used in feed, especially of by-products, is relevant because there are evident variations due to the lack of standardization in the productive processes. Poultry meal is a crushed, powdered, semi-defatted product, resulting from the cooking of raw material originated in the slaughter of birds, consisting of meat parts, viscera, heads, feet and other organs, except feathers and blood removed in the animal's bleeding. Pig meal is a crushed, powdered, semi-defatted product resulting from the cooking of raw material of swine origin, consisting mainly of meat, offal and bones of swine. Hydrolyzed feather meal is a ground, powdered product resulting from the hydrolysis of feathers originating from the slaughter of birds.

The objective of this study was to characterize the centesimal and energetic composition, digestibility, and microbiological quality of animal-origin meals used in non-ruminant feeds, to keep the database update (matrices) and to improve the nutrient estimation for AOM's.

\section{Material and Methods}

The evaluations were performed on animal meal samples - OMA $(n=210)$ from a Meal and Fat Factory (QFP) connected to a refrigerator located in Rio Verde, Goiás, Brazil. A sample of each load received collected, totaling in 70 days collection for evaluation. The studied ingredients were hydrolyzed feather meal - HFM $(n=70)$, poultry meal - POM $(n=70)$ and pig meal - SOM $(\mathrm{n}=70)$.

The AOM processed in a cylindrical digester with a heat jacket, and with a capacity of 6,750 liters. The cooking process occurred in 35 minutes at a pressure of $2.0 \mathrm{kgf} \mathrm{cm}^{-2}$. Pre-drying 
then carried out in the digester for 20 min., and the AOM discharged in a percolator, routed through a propeller thread to a primary rotary dryer, with a temperature of $\cong 120^{\circ} \mathrm{C}$. The ingredients subsequently passed to a secondary rotary dryer, reaching a temperature of $100^{\circ} \mathrm{C}$. Milling carried out in a hammer mill in the last stage.

Near Infrared Reflectance Spectroscopy (NIRS) determined the following variables: moisture (M), crude protein (CP), amino acids, ethereal extract (EE), and ash content (AC). Peroxide (PL) and acidity (AL) levels were determined to evaluate the oxidative process. Analyses followed the methodologies described in the Brazilian Compendium of Animal Feeding (Sindirações, 2013).

Nitro-perchloric digestion (wet digestion) used for calcium $(\mathrm{Ca})$ and phosphorus $(\mathrm{P})$ quantification in the samples. Visible spectrophotometry in the Exata Laboratory (Jataí-GO, Brazil); and $\mathrm{Ca}$ determined phosphorus content by atomic absorption spectrophotometry (GBC-932 AA, Scientific Equipment PTY LTD, Melbourne, Australia) readings performed in spectrophotometer at $660 \mathrm{~nm}$.

The microbiological quality of AOM evaluated by the presence/absence of Salmonella spp. The technique used was Enzyme Linked Fluorescent Assay (ELFA) in the VIDAS ${ }^{\circledR}$ automated system, according to AOAC recommendations (2005).

Protein digestibility was determined using a pepsin assay $(0.002 \%)$, carried out in an oven while stirring. The in vitro pepsin digestibility test has a useful purpose and place in the industry. It turns out that this test used more broadly to make more far-reaching decisions for what it truly intended. Many people see the results of this test as "black and white," reliable and hassle free. In reality, the in vitro pepsin digestibility test is an approximation, an indicator correlated with the true state of affairs, but not a complete, unclear or definite picture. One gram of each sample weighed in a $250-\mathrm{ml}$ Erlenmeyer, adding $75 \mathrm{ml}$ of pepsin in solution. The flask capped and incubated for 63 hours at $45^{\circ} \mathrm{C}$. The contents of the incubation flask transferred to a tube and centrifuged for $10 \mathrm{~min}$. The supernatant then filtered through qualitative filter paper in $100 \mathrm{~mL}$ beaker. From the aliquot, $10 \mathrm{ml}$ of the filtered extract transferred to a macro tube, and the protein content quantified by following the method of Kjeldahl (Sindirações, 2013).

The determination of Metabolizable Energy and Metabolizability values of nutrients/or ingredients is carried out by means of nutritional tests, including metabolism tests which require a period of adaptation for animals and facilities. Another more viable alternative for companies that need immediate results is the use of prediction equations, which in this case provides the Apparent Metabolizable Energy that made by calculating the difference in gross food energy by excreted corrected for metabolic and fecal energy losses endogenous urination. The Apparent Metabolizable Energy (AME) verified by indirect method using prediction equations. Sieves with 3.0 and $1.5 \mathrm{~mm}$ meshes used in the FAO grain size analysis, following a mesh-opening ascending order (bottom-up). One hundred grams of each sample weighed and sieved manually (30 abrupt moves within $10 \mathrm{~min}$ ). Then, the sum of the mass retained on each sieve was determined, together with a granulometric percentage. 
The data submitted to a descriptive statistical analysis. We opted to use the relative dispersion test, i.e. Pearson's coefficient of variation $(\mathrm{CV})$, so we could analyze the dispersion of the means.

\section{Result and Discussion}

Table 1 describes the centesimal composition and energy values of the evaluated animal-origin meals.

Table 1. Bromatological composition and energy value of animal-origin meals ( $\mathrm{n}=70$ samples of each ingredient)

\begin{tabular}{cccccccc}
\hline Ingredient & Moisture \% & $\begin{array}{c}\text { Crude } \\
\text { Protein } \%\end{array}$ & $\begin{array}{c}\text { Ethereal } \\
\text { Extract } \%\end{array}$ & Ash \% & Calcium \% & Phosphorous \% & $\begin{array}{c}\text { AME }^{1} \\
\text { kcal/kg }\end{array}$ \\
\hline $\mathrm{HFM}^{2}$ & 5.86 & 82.93 & 9.15 & 3.07 & 0.62 & 0.42 & 2.863 \\
$\mathrm{CV}^{3}(\%)$ & 14.80 & 1.34 & 6.64 & 10.42 & 24.92 & 37.78 & 10.20 \\
\hline $\mathrm{POM}^{4}$ & 7.11 & 55.10 & 17.16 & 18.45 & 5.67 & 2.98 & 3.008 \\
$\mathrm{CV}^{3}(\%)$ & 7.59 & 2.64 & 6.59 & 1.78 & 15.98 & 15.55 & 7.81 \\
\hline $\mathrm{SOM}^{5}$ & 3.31 & 49.17 & 16.19 & 18.72 & 6.36 & 3.52 & 3.722 \\
$\mathrm{CV}^{3}(\%)$ & 11.80 & 1.91 & 12.33 & 8.00 & 10.77 & 16.65 & 5.50 \\
\hline
\end{tabular}

${ }^{1} \mathrm{AME}=$ Apparent Metabolizable Energy. ${ }^{2} \mathrm{HFM}=$ hydrolyzed feather meal. ${ }^{3} \mathrm{CV}=$ coefficient of variation. ${ }^{4} \mathrm{POM}=$ poultry offal meal. ${ }^{5} \mathrm{SOM}=$ swine offal meal.

The crude protein (CP) percentage of the hydrolyzed feather meal (HFM) verified in this study was $1.73 \%$ higher than the value (Carvalho et al., 2016), whose average was $81.2 \%$. Studied the constitution of HFM and found $80.0 \% \mathrm{CP}, 8.0 \%$ moisture, $2.0 \%$ ethereal extract (EE), and 4.0\% mineral matter (MM) (França et al., 2011).

Regarding apparent metabolizable energy (AME), the value obtained for HFM was similar to that reported in the literature. Eyng et al. (2012) presented 2.758 of $\mathrm{AME}_{\mathrm{n}}$ for feather meal (FM), in the experiment the AME means verified for FM were: 1,772, 2,187, and 2,472 kcal/kg; The Brazilian Table for Poultry and Swine (2017) showed two FM, with 75 and 84\% $\mathrm{BP}$, whose AME were 2,656 and 2,666 kcal/ $\mathrm{kg}$, respectively.

According to Bellaver and Zanotto (2004), offal meal moisture (U) is regularly between 4.0-6.0\%, and should not exceed 10\%. POM presented 7.11\% U, and the swine offal meal (SOM), 3.31\%. The POM moisture was in conformity with the description by The Brazilian Table for Poultry and Swine (2017) 7.0\% for the ingredient mentioned. The lower value observed for SOM may mean overcooking or overfrying, which in turn may be associated 
with equipment wear, excessive retention time, and/or malfunction of gauges and thermometers.

In comparison, the results of $\mathrm{CP}, \mathrm{MM}$, calcium $(\mathrm{Ca})$, phosphorus $(\mathrm{P}), \mathrm{EE}$, and AME of the meals tested were different from those (Eyng et al., 2010; Silva et al., 2012; Troni et al., 2016; The Brazilian Table for Poultry and Swine (2017)). Silva et al. (2012) reported that the amounts of CP, MM, and EE of the offal meal might be influenced by the predominance of certain animal parts, such as head, back, and feet. Still, according to the authors, in Brazil, $47 \%$ of the meal has protein composition of $57.7-61.4 \%$, ash of $11.8-16.20 \%$, and EE of 10.1-16.1\%. The Brazilian Table for Poultry and Swine (2017) described the POM constitution, with CP content of 55.50-57.70\%, and MM of 11.60-15.20\%; as well as SOM, with $47 \% \mathrm{CP}$, and $27.90 \% \mathrm{MM}$.

The mean values of AME ( $\mathrm{kcal} / \mathrm{kg}$ ) for the POM reported were 3,020 (Eyng et al., 2010), 3,545 3,241 and 3,340 (Troni et al., 2016), and 3,241 and 3,682 (The Brazilian Table for Poultry and Swine (2017)). That is, in the literature, the descriptions showed $336 \mathrm{kcal}$ more than what was found in this study. The higher mineral content of the POM probably reverberated to the lower energy content, since the feed had higher EE content.

Differently, the AME in SOM was $3,722 \mathrm{kcal} / \mathrm{kg}$, higher than that found by Fialho et al. (2009), of 3,004 kcal/kg, by Eyng et al. (2010), of 2,145 kcal/kg and by The Brazilian Table for Poultry and Swine (2017) of 2,240 kcal/kg. According to De Marco et al. (2015), the CP and EE content and the composition of fatty acids and minerals contribute to variations in the feed energy values.

Feather meal (FM) consists of a by-product generated by pressure-cooking and subsequent drying of clean, non-decomposed feathers from poultry slaughter. FM hydrolysis is indispensable because due to its keratinized nature, it presents a great amount of sulfur amino acids and resistance to the action of digestive enzymes, making its use difficult for the animal organism (Vidmar \& Vodovnik, 2018; Eyng et al., 2012). For protein availability, acid or alkaline hydrolysis is required for a partial degradation of keratin filaments, making it soluble and digestible (Silva, 2016).

The protein and mineral contents, calcium (Ca), and moisture content of HFM were lower when compared to those described by Carvalho et al. (2012). The differences were probably due to the factors involved in the process of obtaining HFM, such as temperature, cooking time, and material drying time.

The poultry offal meal (POM) characterized as a by-product resulting from cooking, pressing, and grinding of these animals' offal, such as intestines, lungs, carcasses, feet, necks, and bones from mechanically separated meat. It should not contain feathers or residues from a hatchery or other materials that are foreign to its composition (Silva et al., 2011).

The variables EE, calcium $(\mathrm{Ca})$, phosphorus $(\mathrm{P})$, and $\mathrm{AME}$ presented higher values when compared to those of Eyng et al. (2010), Silva et al. (2012), and Troni et al. (2016). The heterogeneity of the processing methods may justify the results. In the case of EE, it may be linked to the digesters' feed forms, as well as to the frying of the meals. It is important to 
consider that some greases add approximately $3.57 \%$ fat to the mass, in order to improve the cooking of the offal. Consequently, this fat is added to that present in the raw material (Silva et al., 2012). The distinct amounts of $\mathrm{Ca}$ and $\mathrm{P}$ presumably came from the proportions of parts (organs) of the birds and swine used. In addition, the technological level of the slaughterhouses may have influenced the minerals contained in the meal, and the greater the use of the meat adhered to the parts, the greater the possibility of the presence of small bone fragments, resulting in higher mineral content.

Table 2 describes the amino acid composition of the animal-origin meals evaluated.

Table 2. Animal meal amino acid composition percentage, ( $\mathrm{n}=70$ samples of each ingredient).

\begin{tabular}{|c|c|c|c|c|c|c|c|c|c|c|c|c|}
\hline $\mathrm{AOM}^{1}$ & $\underset{2}{\operatorname{Arg}}$ & $\mathrm{Cys}^{3}$ & $\begin{array}{c}\text { Phe } \\
4\end{array}$ & $\mathrm{Ile}^{5}$ & $\begin{array}{c}\text { Leu } \\
6\end{array}$ & $\begin{array}{c}\text { Lys } \\
7\end{array}$ & $\operatorname{Met}^{8}$ & $\begin{array}{l}\text { Met+ } \\
\text { Cys }^{9}\end{array}$ & $\begin{array}{c}\operatorname{Thr}^{1} \\
0\end{array}$ & $\begin{array}{c}\mathrm{Val}^{1} \\
1\end{array}$ & $\operatorname{Trp}_{2}^{1}$ & $\underset{3}{\mathrm{His}^{1}}$ \\
\hline HFM & $\begin{array}{c}5.6 \\
8\end{array}$ & 4.59 & $\begin{array}{c}3.8 \\
9\end{array}$ & $\begin{array}{c}3.8 \\
9\end{array}$ & $\begin{array}{c}6.5 \\
9\end{array}$ & $\begin{array}{c}2.0 \\
0\end{array}$ & 0.60 & 5.20 & 3.84 & 5.88 & $\begin{array}{c}0.52 \\
8\end{array}$ & 0.76 \\
\hline $\mathrm{CV}(\%)$ & $\begin{array}{c}1.8 \\
5\end{array}$ & 3.48 & $\begin{array}{c}1.7 \\
4\end{array}$ & 1.7 & $\begin{array}{c}1.7 \\
4\end{array}$ & $\begin{array}{c}5.9 \\
4\end{array}$ & 2.57 & 3.58 & 2.16 & 2.99 & 1.84 & 4.42 \\
\hline POM & $\begin{array}{c}3.3 \\
3\end{array}$ & 0.60 & $\begin{array}{c}1.7 \\
8\end{array}$ & $\begin{array}{c}1.7 \\
7\end{array}$ & $\begin{array}{c}3.1 \\
5\end{array}$ & $\begin{array}{c}2.6 \\
1\end{array}$ & 0.88 & 1.52 & 1.75 & 2.13 & 0.38 & 1.00 \\
\hline $\mathrm{CV}(\%)$ & $\begin{array}{c}6.3 \\
3\end{array}$ & $\begin{array}{c}15.7 \\
9\end{array}$ & $\begin{array}{c}7.1 \\
5\end{array}$ & $\begin{array}{c}7.7 \\
7\end{array}$ & $\begin{array}{c}7.2 \\
6\end{array}$ & $\begin{array}{c}8.8 \\
3\end{array}$ & 8.6 & 8.32 & 7.95 & 7.58 & 7.91 & 5.85 \\
\hline SOM & $\begin{array}{c}3.0 \\
0\end{array}$ & 0.46 & $\begin{array}{c}1.6 \\
2\end{array}$ & $\begin{array}{c}1.4 \\
1\end{array}$ & $\begin{array}{c}2.8 \\
0\end{array}$ & $\begin{array}{c}2.3 \\
8\end{array}$ & 0.77 & 1.11 & 1.54 & 1.99 & 0.34 & 1.01 \\
\hline $\mathrm{CV}(\%)$ & $\begin{array}{c}4.6 \\
3\end{array}$ & 9.55 & $\begin{array}{c}5.3 \\
3\end{array}$ & $\begin{array}{c}6.3 \\
1\end{array}$ & $\begin{array}{c}5.7 \\
0\end{array}$ & $\begin{array}{c}7.5 \\
2\end{array}$ & $\begin{array}{c}19.4 \\
3\end{array}$ & 18.90 & 5.84 & 5.74 & 8.05 & 6.70 \\
\hline
\end{tabular}

${ }^{1} \mathrm{AOM}=$ animal-origin meals. ${ }^{2} \mathrm{Arg}=\operatorname{arginine} ;{ }^{3} \mathrm{Cys}=$ cystine; ${ }^{4} \mathrm{Phe}=$ phenylalanine $;{ }^{5} \mathrm{Ile}=$ isoleucine $;{ }^{6} \mathrm{Leu}=$ leucine $;{ }^{7} \mathrm{Lys}=$ lysine $;{ }^{8} \mathrm{Met}=$ methionine $;{ }^{9} \mathrm{Met}+\mathrm{Cys}=$ methionine + cystine; ${ }^{10} \mathrm{Thr}=$ threonine; ${ }^{11} \mathrm{Val}=$ valine $;{ }^{12} \mathrm{Trp}=$ tryptophan $;{ }^{13} \mathrm{His}=$ histidine.

There were deficiencies of essential amino acids in HFM - lysine, methionine, tryptophan, and histidine; and higher amounts of methionine + cystine, threonine, and isoleucine when compared to the results Li \& Wu (2018) and The Brazilian Table for Poultry and Swine (2017). Cystine had greater variation, and the content measured was higher than that verified by the researchers mentioned above. This fact may have been due to the thermal-sensitivity of the by-product, influenced by the processing conditions.

Carvalho et al. (2012) determined isoleucine (3.84\%), leucine $(6.71 \%)$, and valine $(5.84 \%)$ in 


\section{Al Macrothink}

Journal of Agricultural Studies

ISSN 2166-0379

2020, Vol. 8, No. 1

FM. The authors' results were lower than those estimated for HFM in this study were. According to Silva et al. (2012), the relationship between valine, leucine, and isoleucine been increasingly discussed, since these amino acids show specificity for the same system of membrane transporters, and use the same enzymes for this purpose.

The amino acids constituting the POM had a lower percentage than those of Fernandes et al. (2011) for POM (64.14 and 68.33\%), from Cao and Adeola (2016) for POM (63.42\%), as well as from The Brazilian Table for Poultry and Swine (2017) for POM (55.3 and 57.7\% $\mathrm{CP}$ ). The SOM studied presented constitution similar to the one described by The Brazilian Table for Poultry and Swine (2017) for lysine, methionine, isoleucine, histine, and methionine + cystine. The other SOM amino acids maintained their amounts smaller than did those found by Eyng et al. (2010) and The Brazilian Table for Poultry and Swine (2017).

For many years, poultry and swine feeds formulated based on the $\mathrm{CP}$ concept, which, for the most part, caused diets to have imbalanced amino acid levels, resulting in an excess of many of them. With the advances in animal nutrition, it was possible to establish how much of these nutrients animals really need, and then provide them with adequate amounts without excess or deficiencies, constituting the ideal protein concept (Prabu et al., 2017; Ribeiro and Oelke 2013). Thus, the need arose to evaluate the amino acids constituting the ingredients that will be part of the feeds, such as non-alternative feeds and/or by-products.

In general, the amino acid estimates varied according to the meal crude protein content, being different from those reported in the literature (Spranghers et al., 2017; Eyng et al., 2010; Carvalho et al., 2012; Silva et al., 2012; Cao and Adeola 2016; The Brazilian Table for Poultry and Swine (2017).

The feather meal (FM) has a high cystine content, which in turn is contained in feather keratin, which makes feed use difficult due to the hydrogen bonds, and this contributes to maintaining great protein stability when attacked by enzymes. The modification of the FM cystine amount is directly related to $\mathrm{CP}$ content, raw materials, and processing conditions (Maciel et al., 2017).

Protein sources are ingredients that contribute to the rising cost of bird diets. Therefore, it is necessary to use technologies that provide the best nutritional utilization of this ingredient by animals, such as proteolytic enzymes. The use of enzymes is one of the technologies used to improve the nutritional characteristics of FOA by increasing feed quality. Proteases can degrade proteins by releasing peptides and amino acids and other nutrients to animals (Silva et al., 2018).

Table 3 shows the grain size, digestibility, and microbiological quality of the AOM studied. 
Table 3. AOM grain size, digestibility, and microbiological quality $(n=70$ samples of each ingredient)

\begin{tabular}{|c|c|c|c|c|c|c|}
\hline \multirow[b]{2}{*}{ Ingredient } & \multicolumn{2}{|c|}{ Retention Sieves } & \multirow{2}{*}{$\begin{array}{l}\text { Protein Digestibility } \\
\text { in Pepsine }{ }^{1} \%\end{array}$} & \multirow{2}{*}{$\begin{array}{c}\text { Acidity } \\
\%\end{array}$} & \multirow{2}{*}{$\begin{array}{l}\text { Peroxide / } \\
\mathrm{mEq}\end{array}$} & \multirow{2}{*}{$\begin{array}{c}\text { Salmonella } \\
25 \mathrm{~g}\end{array}$} \\
\hline & $\begin{array}{c}\text { Mesh } \\
3.0 \mathrm{~mm}\end{array}$ & $\begin{array}{c}\text { Mesh } \\
1.5 \mathrm{~mm}\end{array}$ & & & & \\
\hline HFM & 19.98 & 63.94 & 27.72 & 0.91 & 4.59 & \multirow[b]{2}{*}{ Absent } \\
\hline $\mathrm{CV}(\%)$ & 24.50 & 15.26 & 32.50 & 33.52 & 50.04 & \\
\hline POM & 25.09 & 68.70 & 45.71 & 1.74 & 1.59 & \multirow[b]{2}{*}{ Absent } \\
\hline $\mathrm{CV}(\%)$ & 22.95 & 9.69 & 10.38 & 34.29 & 56.27 & \\
\hline SOM & 37.89 & 56.32 & 50.60 & 1.34 & 1.74 & \multirow[b]{2}{*}{ Absent } \\
\hline $\mathrm{CV}(\%)$ & 17.52 & 12.33 & 13.66 & 18.48 & 32.98 & \\
\hline
\end{tabular}

The AOM should not present pathogenic bacteria, and Salmonella sp. should be absent in 25 $\mathrm{g}$ of the sample considered (Brazil, 2008).

According to Sindirações (2013), the ideal texture for an AOM characterized by non-retention in a $3.5 \mathrm{~mm}$ mesh sieve, and a maximum of $10 \%$ of sieve accumulation with a $1.5 \mathrm{~mm}$ mesh. The samples evaluated were out of the desired specifications. The grain size analysis refers to a control parameter, which makes the performance of new grinding and/or adaptation of the equipment possible in order to comply with the requirements. However, it should be noted that adaptations and/or corrections generate additional costs to the production process (Costa et al., 2008).

The oxidative and hydrolytic rancidity indicators of the different AOM studied, acidity, and peroxide index (PI) met the recommendations of Sindirações (2013). The results were lower than were those reported by Fernandes et al. (2011), who evaluated the quality of the POM produced by independent cold stores or industries, in the different seasons of the year. Researchers reported a PI higher than $10 \mathrm{mEq} / \mathrm{g}$ in spring and acidity higher than $3.0 \mathrm{mg}$ $\mathrm{NaOH} / \mathrm{g}$ in the summer when the AOM in this study analyzed.

The protein digestibility of offal meal was inferior to those described by Murakami et al. (2018) of $84.84 \%$ and by Kawauchi et al. (2014) of 67.5\%. The lowest digestibility verified in the HFM, whose value was $27.72 \%$.

The AOM characteristics make them susceptible to deterioration by pathogenic microorganisms when not properly treated (Ruis et al., 2013; Fujihara et al., 2014). The samples evaluated were in conformity with the national hygienic-sanitary standard. High 
temperatures during $\mathrm{AOM}$ processing eliminate much or even all bacterial contamination. However, care should be taken with subsequent activities, such as handling and/or transportation, which can contaminate meals.

The occurrence of free fatty acids in feeds serves as an indication of hydrolytic rancidity (rancid). This occurs in situations of high moisture, favoring the elevation of the enzyme lipase produced by bacteria. Thus, high acidity usually associates with a high bacterial population (Coradi et al., 2011; Matias et al., 2012). According to the recommendations of Sindirações (2013), the maximum value for acidity should be $3.0 \mathrm{mg} \mathrm{NaOH}$ per gram of sample, and for the peroxide index, it should not exceed $5.0 \mathrm{mEq} / 1000 \mathrm{~g}$.

Carollo (2013) monitored the quality of meat and bone meal (MBM) during prolonged storage (10 weeks) and evaluated the addition of antioxidant (BHT - $500 \mathrm{mg} / \mathrm{kg}$ ) to MBM. The authors did not verify changes in acidity; however, there was an increase in the IP of the control lot, which exceeded the maximum limit, reaching $80 \mathrm{mEq} / \mathrm{kg}$ at 56 days of storage. The effect of antioxidant addition on the preservation of MBM quality seen when BHT was added at day zero or seven. However, when the oxidation process had already started, the addition of BHT did not have the desired effect on PI.

The AOM studied in the present experiment had antioxidant addition, and storage time was less than one week. Furthermore, PI is questionable because it is a punctual analysis, which can be performed after the peroxide formation peak, in which these compounds are transformed into secondary ones, such as ketones and aldehydes (Valle, 2010).

The processing of animal meals in the grease, specifically temperature, pressure, and time employed, can compromise the product quality either by charring organic matter, reducing total digestibility or by making specific amino acids unavailable. These variations directly reflect on the protein quality of ingredients, which can cause large differences between by-products (Glencross et al., 2019).

According Eyng et al. (2012), low biological values of HFM are based on protein content, in natura material, and processing conditions. Regarding operational procedures, low-pressure cases may require a long hydrolysis time and, if it does not occur completely, digestibility becomes compromised.

The lack of standardization of operational processes and the constituents of raw materials are the main causes of differences in the chemical and energy compositions of the animal-origin meal - AOM.

AOM are predisposed to damage by oxidative processes, as well as by contamination by pathogenic microorganisms. Thus, a routine of verification of components and quality of the AOM that will be used in feeds for monogastric animals must be established

The Brazilian Compendium of Animal Feed (CBAA, 2013) presents the quality specifications for animal meal. For poultry viscera flour, the values are $8 \%$ moisture (maximum), 55\% crude protein (minimum), 60\% pepsin digestibility, $10 \%$ ethereal extract (minimum) and 15\% mineral matter (maximum). In porcine meal the specification is $8 \%$ moisture (maximum), 
$55 \%$ crude protein (minimum), $85 \%$ pepsin digestibility, $15 \%$ ethereal extract (minimum) and $33 \%$ mineral matter (maximum). For beef and bone meal, the specifications are $8 \%$ moisture (maximum), 55\% crude protein (minimum), 30\% pepsin digestibility, 10\% ether extract (minimum) and 28\% mineral matter (maximum).

\section{Conclusion}

The results found in this work demonstrated that the ingredients meet the quality requirements required by the Brazilian Legislation and, is essential since it makes the adequate and beneficial destination of the residues generated by the productive chains of the meat (slaughter) possible, mitigating possible impacts to the environment. Furthermore, it allows to reduce the livestock activity costs and to propitiate its sustainability.

\section{References}

Aguiar, G. P. S., Limberger, G. M., \& Silveira, E. L. (2014). Alternativas tecnológicas para o aproveitamento de resíduos provenientes da industrialização de pescados. Revista eletrônica interdisciplinar, 1(11).

Associação Brasileira de Reciclagem Animal - ABRA. (2016). II Diagnóstico da indústria brasileira de reciclagem animal. Brasília-DF: ABRA, 85p.

Association of Official Agricultural Chemists - AOAC. (2005). Official methods of analysis of AOAC international. 18th.ed. Gaithersburg, Unites States of America: AOAC International.

Bellaver, C., \& Zanotto, D. L. (2004). Parâmetros de qualidade em gorduras e subprodutos protéicos de origem animal. In: Conferência APINCO de Ciências e Tecnologia Avícolas. Anais... Campinas-SP: FACTA, 79-102.

BRASIL, MINISTÉRIO DA AGRICULTURA, PECUÁRIA E ABASTECIMENTO - MAPA. (2008). Instrução Normativa n: 34 , de 28 de maio 2008. Available at http://sistemasweb.agricultura.gov.br/sislegis/action/detalhaAto.do?method=visualizarAtoPor talMapa\&chave $=284275208$ Accessed on Apr. 23, 2017, at 04:50 pm

Buentello, A., Seoka, M., \& Suarez, J. (2016). Nutrição de espécies de atum cultivadas. Em Advances in Aquacultura de atum (pp. 273-321). Imprensa Acadêmica. https://doi.org/10.1016/B978-0-12-411459-3.00012-6

Cao, M. H., \& Adeola, O. (2016). Energy value of poultry byproduct meal and animal-vegetable oil blend for broiler chickens by the regression method. Poultry Science, 95(2), 268-275. https://doi.org/10.3382/ps/pev317

Carollo, V. (2013). Dietary interventions to improve healthy status in pig intensive farm conditions: a morpho-functional study of target organs

Carvalho, C. M. C., Fernandes, E. A., \& Carvalho, A. P. (2012). Uso de farinhas de origem animal na alimentação de frangos de corte. Revista Portuguesa de Ciências Veterinárias, 107(581-582), 69-73. 
Coradi, P. C., Lacerda, A. F., \& Melo, E. C. (2011). Quality of raw materials from different regions of Minas Gerais State utilized in ration industry. Revista Brasileira de Engenharia Agrícola e Ambiental, 15(4), 424-431. https://doi.org/10.1590/S1415-43662011000400015

Costa, D. P. S., Romanelli, P. F., \& Trabuco, E. (2008). Aproveitamento de vísceras não comestíveis de aves para elaboração de farinha de carne. Ciência e Tecnologia de Alimentos, 28(3), 746-752. https://doi.org/10.1590/S0101-20612008000300035

De Marco, M., Martínez, S., Hernandez, F., Madrid, J., Gai, F., Rotolo, L., \& Kovitvadhi, A. (2015). Nutritional value of two insect larval meals (Tenebrio molitor and Hermetia illucens) for broiler chickens: apparent nutrient digestibility, apparent ileal amino acid digestibility and apparent metabolizable energy. Animal Feed Science and Technology, 209, 211-218. https://doi.org/10.1016/j.anifeedsci.2015.08.006

Eyng, C., Nunes, R. V., \& Albino, L. F. T. (2012). Composição química e aminoacídica e coeficientes de digestibilidade verdadeira dos aminoácidos de farinhas de penas e sangue determinados em galos cecectomizados. Revista Brasileira de Zootecnia, 41(1), 80-85. https://doi.org/10.1590/S1516-35982012000100012

Eyng, C., Nunes, R. V., \& Rostagno, H. S. (2010). Composição química, valores energéticos e aminoácidos digestíveis verdadeiros de farinhas de vísceras para aves. Revista Brasileira de Zootecnia, 39(4), 779-786. https://doi.org/10.1590/S1516-35982010000400012

Fernandes, V. A. G., Enke D. B. S., \& Fracalossi, D. M. (2011). Avaliação da qualidade da farinha de vísceras de aves produzidas por frigoríficos ou indústrias independentes, nas diferentes estações do ano. Revista Graxaria Brasileira, 21(3), 62-63.

Fialho E. T., Silva, H. O., \& Zangeronimo, M. G. (2009). Alimentos alternativos para suínos. Lavras-MG: UFLA/FAEPE, 232p.

França, J., Saad, F. M. O. B., \& Saad, C. E. P. (2011). Avaliação de ingredientes convencionais e alternativos em rações de cães e gatos. Revista Brasileira de Zootecnia, 40, 222-231.

Fujihara, R. I., Schons, S. V., \& Ferreira, E. (2014). Produção de farinha de carne e ossos: regulamentações sanitárias e ambientais. Revista Brasileira de Ciências da Amazônia, 3(1), $1-14$.

Geraldes, A. (2014). A Reciclagem Animal diante da Política Nacional de Resíduos Sólidos. Revista Graxaria Brasileira: Reciclagem Animal, 7, ed. 39.

Glencross, B. D., Baily, J., Berntssen, M. H., Hardy, R., MacKenzie, S., \& Tocher, D. R. (2019). Risk assessment of the use of alternative animal and plant raw material resources in aquaculture feeds. Reviews in Aquaculture. https://doi.org/10.1111/raq.12347

Kawauchi, I. M., Sakomura, N. K., \& Pontieri, C. F. F. (2014). Prediction of crude protein digestibility of animal by-product meals for dogs by the protein solubility in pepsin method. Journal of Nutritional Science, 3(36), 01-05. https://doi.org/10.1017/jns.2014.32 
Li, P., \& Wu, G. (2018). Roles of dietary glycine, proline, and hydroxyproline in collagen synthesis and animal growth. Amino acids, 50(1), 29-38. https://doi.org/10.1007/s00726-017-2490-6

Maciel, J. L., Werlang, P. O., Daroit, D. J., \& Brandelli, A, (2017). Characterization of protein-rich hydrolysates produced through microbial conversion of waste feathers. Waste and biomass valorization, 8(4), 1177-1186. https://doi.org/10.1007/s12649-016-9694-y

Matias, C. F. Q., Lara, L. J. C., \& Baião, N. C. (2012). Utilização de farinhas de origem animal na avicultura. Revista Eletrônica Nutritime, 9(5), 1944-1964.

Murakami, F. Y., de Lima, D. C., Menezes Souza, C. M., Kaele, G. B., Oliveira, S. G. D., \& Félix, A. P. (2018). Digestibility and palatability of isolated porcine protein in dogs. Italian Journal of Animal Science, 17(4), 1070-1076. https://doi.org/10.1080/1828051X.2018.1443404

Prabu, E., Felix, S., Felix, N., Ahilan, B., \& Ruby, P. (2017). An overview on significance of fish nutrition in aquaculture industry. International Journal of Fisheries and Aquatic Studies, 5(6), 349-355.

Reis, R. S., Barreto, S. L. T., \& Viana, G. S. (2013). Inclusão de farinha de vísceras na ração de codornas japonesas em postura. Brazilian Journal of Sustainable Agriculture, 3(1), 158-163.

Ribeiro, A. M. L., \& Oelke, C. A. (2013). Como formular rações para reduzir a capacidade poluente sem afetar o desempenho. In: VIII Simpósio Internacional de Suinocultura SINSUI. Anais... Porto Alegre-RS:, 1, 159-178, 2013.

Rostagno, H. S., Albino, L. F. T., \& Hannas, M. I. (2017). Tabelas brasileiras para aves e suínos: composição de alimentos e exigências nutricionais. 4.ed. Viçosa-MG: Departamento de Zootecnia/UFV, 488p.

Ruis, M., Salvatori, R. U., \& Majolo, C. (2013). Número mais provável de Salmonella sp. em farinhas de origem animal. Destaques Acadêmicos (CCBS/Univates), 5(3), 41-47.

Silva, E. P., Rabello, C. B. V., \& Lima, M. B. (2012). Determination of the chemical composition, amino acid levels and energy values of different poultry offal meals for broilers. Brazilian of Journal Poultry Science, 14(2), 71-158. https://doi.org/10.1590/S1516-635X2012000200003

Silva, J. C. T. (2016). Utilização do farelo de castanha do Brasil em rações para frangos de corte de linhagem caipira. Dissertação [Mestrado em Sanidade e Produção Animal Sustentável na Amazônia Ocidental]. Rio Branco-AC: Universidade Federal do Acre, 66p.

Silva, J. M. S., Gouveia, A. B. V. S., Da Silva, W. J., De Paulo, L. M., Dos Santos, F. R., \& Minafra, C. S. (2018). Uso de enzimas para aumentar a qualidade nutricional de farinhas de origem animal. PUBVET, 12, 133. https://doi.org/10.31533/pubvet.v12n8a156.1-13

SINDICATO NACIONAL DA INDÚSTRIA DE ALIMENTAÇÃO ANIMAL - 


\section{Macrothink}

SINDIRAÇÕES. Compêndio de alimentação animal. 4.ed. São Paulo-SP: SINDIRAÇÕES, 2013. 567p.

Spranghers, T., Ottoboni, M., Klootwijk, C., Ovyn, A., Deboosere, S, De Meulenaer, B., \& De Smet, S. (2017). Nutritional composition of black soldier fly (Hermetia illucens) prepupae reared on different organic waste substrates. Journal of the Science of Food and Agriculture, 97(8), 2594-2600. https://doi.org/10.1002/jsfa.8081

Troni, A. R., Gomes, P. C., \& Mello, H. H. C. (2016). Composição química e energética de alimentos para frangos de corte. Revista Ciência Agronômica, 47(4), 755-760.

Valle, F. L. P. (2010). Uso de fitase em dietas comerciais para frangos de corte contendo ou não ingrediente de origem animal. Dissertação [Mestrado em Ciências Veterinárias] Curitiba-PR: Universidade Federal do Paraná - UFPR, 91p.

Vidmar, B., \& Vodovnik, M. (2018). Queratinases Microbianas: Enzimas com Aplicações Biotecnológicas Promissoras. Tecnologia de alimentos e biotecnologia, 56(3), 312-328.

\section{Copyright Disclaimer}

Copyright for this article is retained by the author(s), with first publication rights granted to the journal.

This is an open-access article distributed under the terms and conditions of the Creative Commons Attribution license (http://creativecommons.org/licenses/by/4.0/). 